\title{
MIRLET7C Gene
}

National Cancer Institute

\section{Source}

National Cancer Institute. MIRLET7C Gene. NCI Thesaurus. Code C80708.

This gene is involved in the regulation of gene expression and plays a tumor suppressor role in lung, prostate and ovarian carcinomas, acute promyelocytic leukemia and Burkitt lymphoma.. 